\title{
Miracle Fruit (Synsepalum dulcificum) Exhibits as a Novel Anti-Hyperuricaemia Agent
}

\author{
Yeu-Ching Shi ${ }^{1}$, Kai-Sian Lin ${ }^{2}$, Yi-Fen Jhai ${ }^{2}$, Bao-Hong Lee ${ }^{3,4}$, Yifan Han ${ }^{5}$, Zhibin Cui ${ }^{6}$, \\ Wei-Hsuan $\mathrm{Hsu}^{7, *}$ and She-Ching $\mathrm{Wu}^{2, *}$ \\ 1 Taiwan Indigena Botanica Co., Ltd., Taipei 11458, Taiwan; jasmineycs@yahoo.com.tw \\ 2 Department of Food Sciences, National Chiayi University, Chiayi 60004, Taiwan; \\ Tracy12095238@hotmail.com (K.-S.L.); even78819@gmail.com (Y.-F.J.) \\ 3 Division of Hematology and Oncology, Department of Internal Medicine, \\ Taipei Medical University Hospital, Taipei 11042, Taiwan; f96b47117@ntu.edu.tw \\ 4 Department of Traditional Chinese Medicine, Taipei Medical University Hospital, Taipei 10042, Taiwan \\ 5 Department of Oral Pathology, Ninth People's Hospital, Shanghai Jiao Tong University School of Medicine, \\ Shanghai 200092, China; yifanhan2014@gmail.com \\ 6 Department of Comparative Pathobiology, Purdue University, West Lafayette, IN 47907, USA; \\ cuizhibin1985@gmail.com \\ 7 Biochemical Process Technology Department, Center of Excellence for Drug Development, \\ Biomedical Technology and Device Research Laboratories, Industrial Technology Research Institute, \\ Hsinchu 30058, Taiwan \\ * Correspondence: d99b22003@ntu.edu.tw (W.-H.H.); scwu@mail.ncyu.edu.tw (S.-C.W.); \\ Tel.: +886-3-573-2934 (W.-H.H.); +886-5-271-7622 (S.-C.W.); Fax: +886-5-271-7590 (S.-C.W.)
}

Academic Editor: Maurizio Battino

Received: 31 December 2015 ; Accepted: 20 January 2016 ; Published: 26 January 2016

\begin{abstract}
Miracle fruit (Synsepalum dulcificum) belongs to the Sapotaceae family. It can change flavors on taste buds, transforming acidic tastes to sweet. We evaluated various miracle fruit extracts, including water, butanol, ethyl acetate (EA), and hexane fractions, to determine its antioxidant effects. These extracts isolated from miracle fruit exerted potential for reduction of uric acid and inhibited xanthine oxidase activity in vitro and in monosodiumurate (MSU)-treated RAW264.7 macrophages. Moreover, we also found that the butanol extracts of miracle fruit attenuated oxonic acid potassium salt-induced hyperuricaemia in ICR mice by lowering serum uric acid levels and activating hepatic xanthine oxidase. These effects were equal to those of allopurinol, suggesting that the butanol extract of miracle fruit could be developed as a novel anti-hyperuricaemia agent or health food.
\end{abstract}

Keywords: miracle fruit; xanthine oxidase; monosodium urate (MSU); oxonic acid potassium salt; anti-hyperuricaemia agent

\section{Introduction}

Miracle berry (Synsepalum dulcificum) is also called miracle fruit. It has a large seed that is surrounded by a thin layer of berry flesh with a faint cherry-like flavor [1]. There is growing interest in the potential use of miracle berries in food, as it has the unique ability to make sour foods taste sweet. This effect lasts until miraculin is diluted and eliminated by saliva. Miracle fruit is reported to have antioxidant activities [2] and improves the sweetness of low-calorie desserts without increasing energy compensation. Thus, miracle fruit could represent a novel sweetener for use in food [3].

Gout is an inflammatory disease caused by the over-production of uric acid in the blood and crystallization of monosodiumurate (MSU) in tissues. This process is driven by neutrophil influx into joints, leading to acute inflammatory arthritis with severe pain in the affected tissue. MSU crystals can trigger interleukin- $1 \beta$ maturation via recruitment of a cytosolic complex, called the nucleotide-binding 
oligomerization domain-like receptor pyrindomain containing 3 (NLRP3) inflammasome [4,5]. Redox signalling molecules, such as reactive oxygen species (ROS), are generated by NLRP3 inflammasome activators, including MSU and other endogenous danger signals [6].

Another potential source of cellular ROS is xanthine oxidase; however, its role remains unclear. Xanthine oxidase is a key enzyme in purine catabolism, mediating the formation of uric acid, which can be further broken down to allantoin in mammals that possess uric oxidase (uricase) [7]. Interestingly, several clinical and experimental studies suggest that xanthine oxidase activity has pro-inflammatory effects [8]. Currently, numerous anti-gout agents are available, including non-steroidal anti-inflammatory drugs, such as indomethacin and naproxen. They are frequently used as first-line therapies for acute gout. Nevertheless, their use is limited by adverse reactions, including gastrointestinal toxicity, renal toxicity, and gastrointestinal bleeding. Therefore, the identification of better anti-gout arthritis drugs is necessary.

We hypothesized that the anti-gouty arthritis effects of miracle fruit may be mediated by inhibition of inflammatory cell activation and enhanced antioxidant activity. We evaluated the anti-inflammatory effect of miracle fruit in MSU crystal-treated RAW264.7 macrophages and investigated miracle fruit-induced attenuation of xanthine oxidase activity in animal models. Our results may support the utility of miracle fruit in herbal medicines.

\section{Results and Discussion}

\subsection{Antioxidant Effect and Xanthine Oxidase Suppression Following Miracle Fruit Treatment in Vitro}

Hyperuricaemia results from increased uric acid production impaired renal uric acid excretion. In most patients with primary gout, hyperuricaemia results from inefficient renal excretion. However, in approximately $10 \%$ of cases, hyperuricaemia is due to endogenous uric acid overproduction [9]. Hyperuricaemia is associated with inflammation, mediated by ROS and cytokine generation through inflammasome activation [10]. Furthermore, MSU is reported to trigger oxidative stress and inflammasome activity [6]. MSU is known to activate the inflammasome, thereby triggering oxidative stress and hyperuricaemic-like inflammation in monocytes or macrophages [7]. Antioxidants can have protective effects by blocking MSU-induced inflammasome activation in vitro and in vivo [7,11]. Recent work has shown that miracle fruit has antioxidant properties [2].

As shown in Supplemental Table S1, miracle fruit powder (MFP) has more total phenolic compounds, flavonoids, and anthocyanins than miracle fruit water extract (MFWE). Therefore, MFP exerted greater DPPH and ABTS radicals scavenging activity, and reduced power, as shown in Supplemental Figure S1. Additionally, MFP and MFWE inhibited xanthine oxidase activity (Figure 1). However, MFWE had a dose-dependent effect on xanthine oxidase activity in vitro (Supplemental Figure S2A). We also found that MFWE markedly suppressed xanthine oxidase activity in MSU-treated RAW264.7 macrophages, with $500 \mu \mathrm{g} / \mathrm{mL}$ MFWE exerting a greater effect than $100 \mu \mathrm{g} / \mathrm{mL}$ allopurinol (Supplemental Figure S2B). MFP was partitioned using water, butanol, ethyl acetate (EA), and hexane after extraction with butanol. Total phenolic compounds and flavonoids were measured in these extracts. Our study revealed that the EA fraction contains high levels of phenolic compounds (mg. GAE/g) and flavonoids (5.38 mg. QE/g) (Table 1). The EA fraction exhibited greater xanthine oxidase inhibition than the water, butanol, and hexane fractions (Figure 2). Thus, among the miracle fruit fractions, the EA fraction may exert anti-oxidant activity, including dose-dependent DPPH scavenging activity, ABTS scavenging activity, and power reduction (Figure 3). 


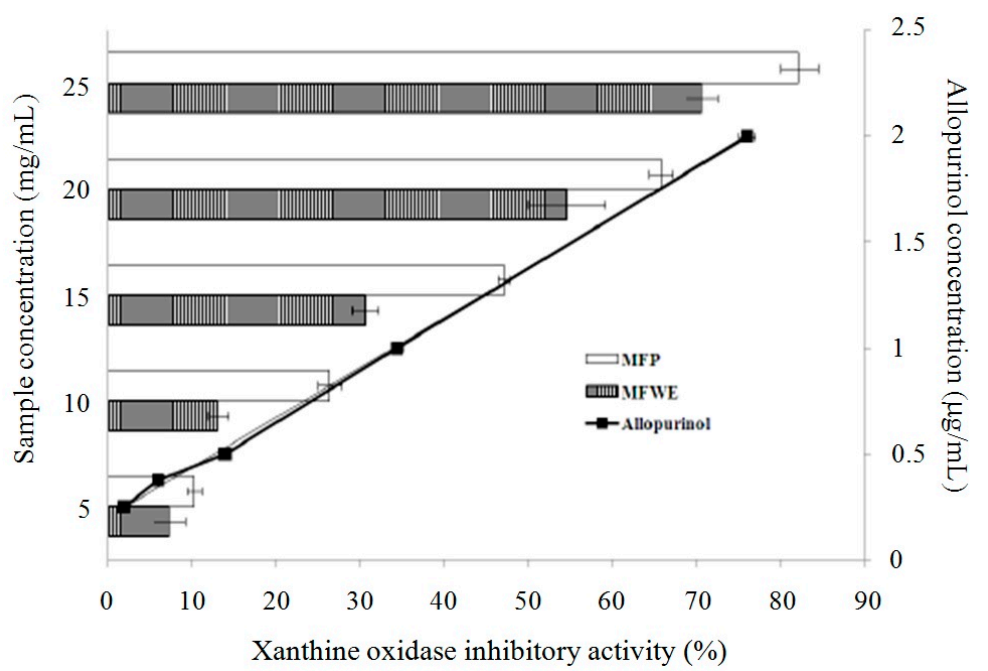

Figure 1. The effects of mircle fruit powder (MFP) and miracle fruit-water extract (MFWE) on xanthine oxides activity in vitro. Allopurinol: positive control. Each value is expressed as mean \pm S.D. $(n=3)$.

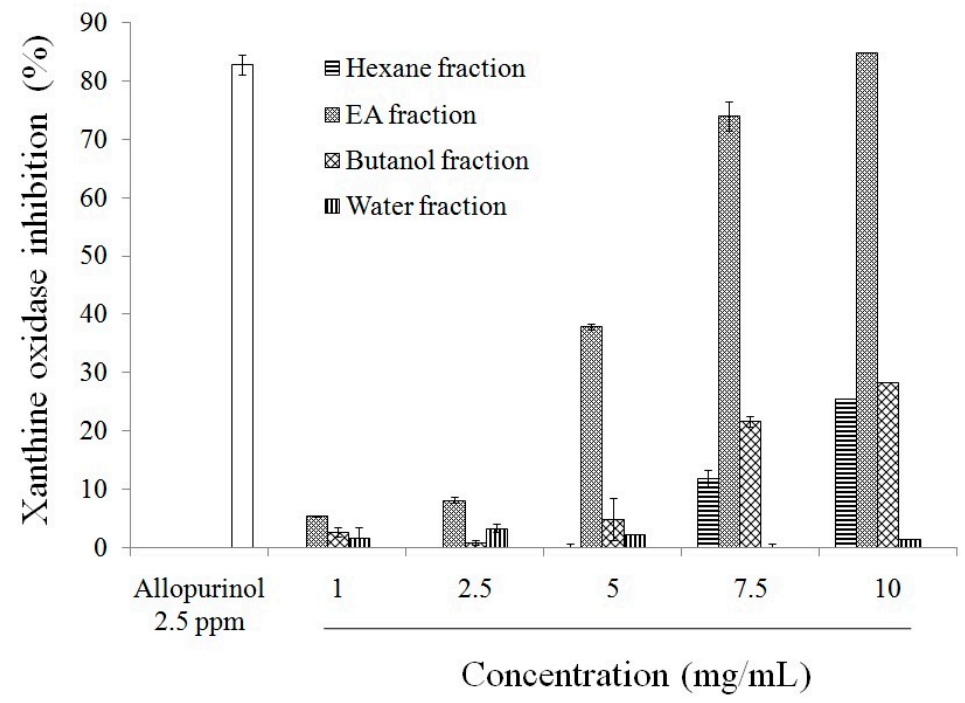

Figure 2. Xanthine oxidase inhibitory activities of different solvent fractions from butanol extract of miracle fruit. Each value is expressed as mean \pm S.D. $(n=3)$. EA: ethyl acetate.
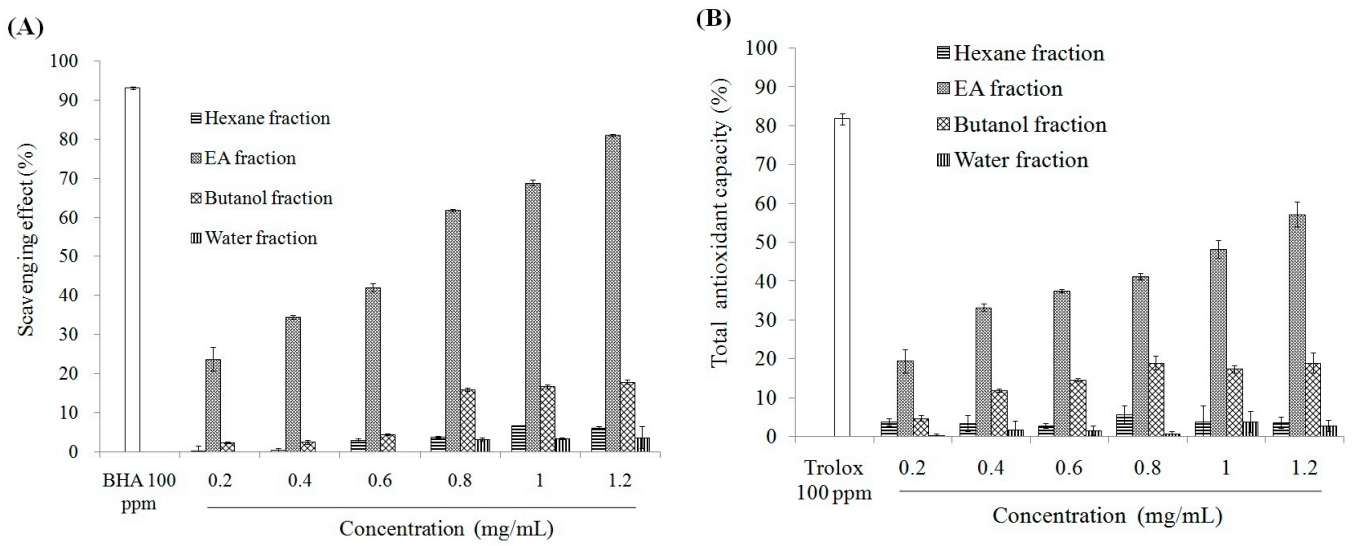

Figure 3. Cont. 


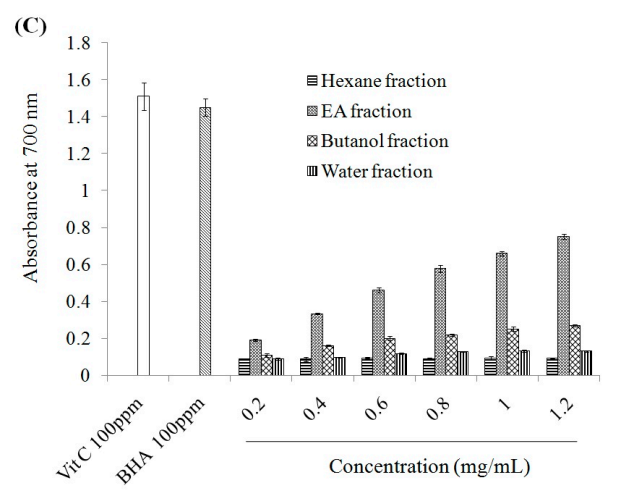

Figure 3. The effects of different solvent fractions from butanol extract of miracle fruit on (A) DPPH radical scavenging capacity; (B) Trolox Equivalent Antioxidant Capacity (TEAC) activity; and (C) reducing power. Each value is expressed as mean \pm S.D. $(n=3)$. EA: ethyl acetate.

Table 1. Total phenolics and flavonoids of different solvent fractions from butanol extracts of miracle fruit.

\begin{tabular}{ccc}
\hline Fractions & Total Phenolics & Flavonoids \\
\hline Water Fraction & $0.91 \pm 0.16^{\mathrm{c}}$ & $1.12 \pm 0.14^{\mathrm{b}}$ \\
Butanol Fraction & $4.15 \pm 0.36^{\mathrm{b}}$ & $1.28 \pm 0.13^{\mathrm{b}}$ \\
EA Fraction & $12.91 \pm 1.15^{\mathrm{a}}$ & $5.38 \pm 0.52^{\mathrm{a}}$ \\
Hexane Fraction & $1.03 \pm 0.99^{\mathrm{c}}$ & $1.32 \pm 0.17^{\mathrm{b}}$
\end{tabular}

Each value is expressed as mean \pm S.D. $(n=3)$. Data bearing different superscript letters $(a-c)$ are significantly different $(p<0.05)$. Total phenolics were accorded to gallic acid equivalent (GAE); flavonoids were accorded to quercetin equivalent $(\mathrm{QE})$.

\subsection{Inhibition of Oxidative Stress in MSU-Treated RAW264.7 Macrophages}

Because the EA fraction had the strongest antioxidant effect and inhibited xanthine oxidase activity, we evaluated the effect of the EA fraction on reactive oxygen species (ROS) generation in RAW264.7 macrophage treated by MSU $(2.5 \mathrm{mg} / \mathrm{mL})$ for $24 \mathrm{~h}$. As shown in Figure 4, the EA fraction $(100-400 \mu \mathrm{g} / \mathrm{mL})$ inhibited ROS generation in MSU-treated RAW264.7 macrophages. Furthermore, $100 \mu \mathrm{g} / \mathrm{mL}$ EA fraction suppressed ROS generation to a similar extent as $100 \mu \mathrm{g} / \mathrm{mL}$ allopurinol. These findings indicate that the anti-uric acid effect of allopurinol occurred independently of oxidative stress inhibition. Taken together, we have shown that the butanol extracts and various miracle fruit fractions, including water, butanol, EA, and hexane fractions, exert antioxidant activity, thereby suppressing ROS generation (Figures 3 and 4; Supplemental Figure S2; Table 1; Supplemental Table S1).

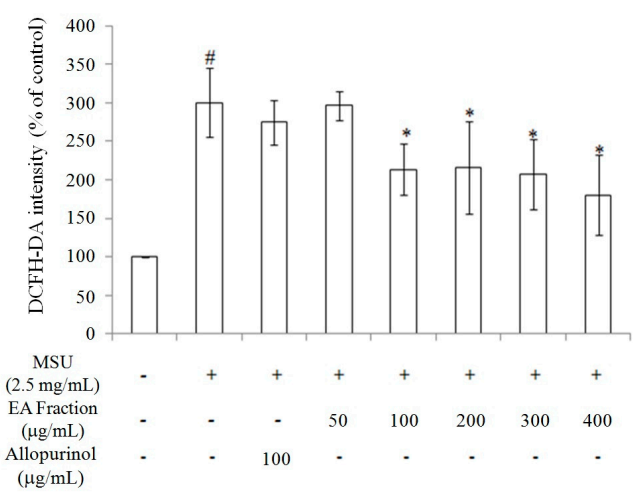

Figure 4. The inhibitory effects of the ethyl acetate (EA) fraction from butanol extract of miracle fruit on reactive oxygen species production in MSU crystal-induced in RAW264.7 cells. Each value is expressed as mean \pm S.D. $(n=3)$. Data bearing different superscript letters (\# and ${ }^{*}$ ) are significantly different $(p<0.05)$. \# Compare with control; * Compare with only MSU. MSU: monosodium urate crystals. 


\subsection{Miracle Fruit Downregulates Uric Acid Levels in Hyperuricaemic Mice}

Xanthine oxidase catalyses hypoxanthine and xanthine oxidation, leading to uric acid formation [12]. Therefore, xanthine oxidase inhibitors may represent potential therapeutic agents to treat hyperuricaemia, as they could be used to block uric acid biosynthesis [13]. Although several medicinal plants are used to prevent and treat hyperuricaemia and gout, based on traditional medicine systems [14,15], use of miracle fruit to treat hyperuricaemic is minimal, due to a lack of formal scientific evidence to support its effectiveness. Miracle fruit contains epicatechin, rutin, quercetin, myricetin, kaempferol, gallic acid, ferulic acid, syringic acid, three anthocyanins (delphinidin glucoside, cyanidin galactoside, and malvidin galactoside), three tocopherols, and lutein [2,16].

The anti-hyperuricaemic effects of miracle fruit were investigated in vivo using ICR mice treated with oxonic acid potassium salt $(250 \mathrm{mg} / \mathrm{kg} \cdot \mathrm{bw})$ for seven days. During the induction period, the mice were orally administered low dose miracle fruit butanol extract (MFL; $500 \mathrm{mg} / \mathrm{kg} \cdot \mathrm{bw} /$ day), high dose miracle fruit butanol extract (HFL; $1000 \mathrm{mg} / \mathrm{kg} \cdot \mathrm{bw} /$ day), or allopurinol $(10 \mathrm{mg} / \mathrm{kg} \cdot \mathrm{bw} /$ day; positive control). Allopurinol is the most commonly used xanthine oxidase inhibitor and is prescribed clinically for gout treatment. However, its use is limited by hypersensitivity, Stevens-Johnson syndrome, renal toxicity, and fatal liver necrosis [17]. Attempts have been made to identify natural compounds that inhibit xanthine oxidase and have fewer side effects, thereby serving as allopurinol [10,18]. Our results suggest that butanol extracts from miracle fruit do not induce side effects in organs (Table 2) or alter serum biochemical parameters in oxonic acid potassium salt-treated ICR mice (Table 3). No significant difference was observed in organs, including the liver and kidneys (Table 2). Additionally, serum creatinine (CRE) and blood urea nitrogen (BUN) levels were unchanged in oxonic acid potassium salt-induced ICR mice, suggesting that there were no toxic effects. Furthermore, no side effects were observed (Table 3).

Table 2. Effect of butanol extract from miracle fruit on relative liver and kidney weight of hyperuricemia mice.

\begin{tabular}{ccc}
\hline \multirow{2}{*}{ Groups } & \multicolumn{2}{c}{ Relative Organ Weight (g/100 g of bw) } \\
\cline { 2 - 3 } & Liver & Kidney \\
\hline Normal & $4.84 \pm 0.51$ & $1.57 \pm 0.14$ \\
NC & $5.12 \pm 0.62$ & $1.58 \pm 0.19$ \\
PC & $4.96 \pm 0.36$ & $1.59 \pm 0.14$ \\
MFL & $5.01 \pm 0.51$ & $1.61 \pm 0.16$ \\
MFH & $5.22 \pm 0.28$ & $1.67 \pm 0.2$
\end{tabular}

Each value is expressed as mean \pm S.D. $(n=5)$. Value in a column with the different superscripts are significantly different $(p<0.05)$. Normal: blank, NC: negative control, PC: positive control (allopurinol, $10 \mathrm{mg} / \mathrm{kg} \cdot \mathrm{bw} /$ day), MFL: low dose administration of miracle fruit (butanol extract, $500 \mathrm{mg} / \mathrm{kg} \cdot \mathrm{bw} /$ day), MFH: high dose administration of miracle fruit (butanol extract, $1000 \mathrm{mg} / \mathrm{kg} \cdot \mathrm{bw} /$ day).

Table 3. Effect of butanol extract from miracle fruit on serum CRE and BUN levels of hyperuricemia mice.

\begin{tabular}{ccc}
\hline \multirow{2}{*}{ Groups } & CRE & BUN \\
\cline { 2 - 3 } & \multicolumn{2}{c}{$\mathbf{m g} / \mathrm{dL}$} \\
\hline Normal & $0.55 \pm 0.06$ & $19.6 \pm 1.1$ \\
NC & $0.65 \pm 0.21$ & $26.3 \pm 3.6$ \\
PC & $0.48 \pm 0.14$ & $22.4 \pm 5.9$ \\
MFL & $0.48 \pm 0.07$ & $22.5 \pm 7.1$ \\
MFH & $0.46 \pm 0.13$ & $22.4 \pm 4.0$ \\
\hline
\end{tabular}

Each value is expressed as mean \pm S.D. $(n=5)$. Value in a column with the different superscripts are significantly different $(p<0.05)$. Normal: blank, NC: negative control, PC: positive control (allopurinol, $10 \mathrm{mg} / \mathrm{kg}$. bw/day), MFL: low dose administration of miracle fruit (butanol extract, $500 \mathrm{mg} / \mathrm{kg} \cdot \mathrm{bw} / \mathrm{day}$ ), MFH: high dose administration of miracle fruit (butanol extract, $1000 \mathrm{mg} / \mathrm{kg} \cdot \mathrm{bw} /$ day). CRE: creatinine; BUN: blood urea nitrogen. 
As shown in Table 4, i.p. injection of oxonic acid potassium salt (negative control) significantly elevated hepatic xanthine oxidase activity in ICR mice, as compared to the normal group. However, HFL and allopurinol markedly attenuated these effects. Similarly, serum uric acid levels were markedly increased by oxonic acid potassium salt, and were suppressed by HFL or allopurinol. Interestingly, the effect of HFL was similar to allopurinol.

Table 4. Effect of butanol extract from miracle fruit on hepatic xanthine oxidase activity of hyperuricemia mice.

\begin{tabular}{cc}
\hline \multirow{2}{*}{ Groups } & Xanthine Oxidase Activity \\
\cline { 2 - 2 } & (nmol/min/mg/protein) \\
\hline Normal & $1.07 \pm 0.31^{\mathrm{ab}}$ \\
NC & $1.35 \pm 0.40^{\mathrm{a}}$ \\
PC & $0.75 \pm 0.11^{\mathrm{b}}$ \\
MFL & $1.02 \pm 0.27^{\mathrm{ab}}$ \\
MFH & $0.82 \pm 0.30^{\mathrm{b}}$ \\
\hline
\end{tabular}

Each value is expressed as mean \pm S.D. $(n=5)$. Value in a column with the different superscripts are significantly different $(p<0.05)$. Normal: blank, NC: negative control, PC: positive control (allopurinol, $10 \mathrm{mg} / \mathrm{kg} \cdot \mathrm{bw} /$ day), MFL: low dose administration of miracle fruit (butanol extract, $500 \mathrm{mg} / \mathrm{kg} \cdot \mathrm{bw} /$ day), MFH: high dose administration of miracle fruit (butanol extract, $1000 \mathrm{mg} / \mathrm{kg} \cdot \mathrm{bw} /$ day).

We hypothesized that the anti-gouty arthritis effects of miracle fruit are caused by antioxidants. Our results indicate that the water, butanol, EA, and hexane fractions of miracle fruit can inhibit xanthine oxidase activity in vitro (Figures 1 and 2) and in MSU-treated RAW264.7 macrophages (Supplemental Figure S2). Moreover, the EA fraction attenuated uric acid accumulation (Figure 5) and hepatic xanthine oxidase activity (Table 4) in oxonic acid potassium salt-treated ICR mice. The pathway by which MSU induces inflammasome activation is well described [19,20]. This study investigated the potential capacity of miracle fruit to inhibit hyperuricaemia in vitro and in vivo. However, the mechanism by which miracle fruit extract exerts its effects remains unclear. Thus, the potential pathways and major compounds in miracle fruit extract regulating hyperuricaemia need to be investigated in the future.

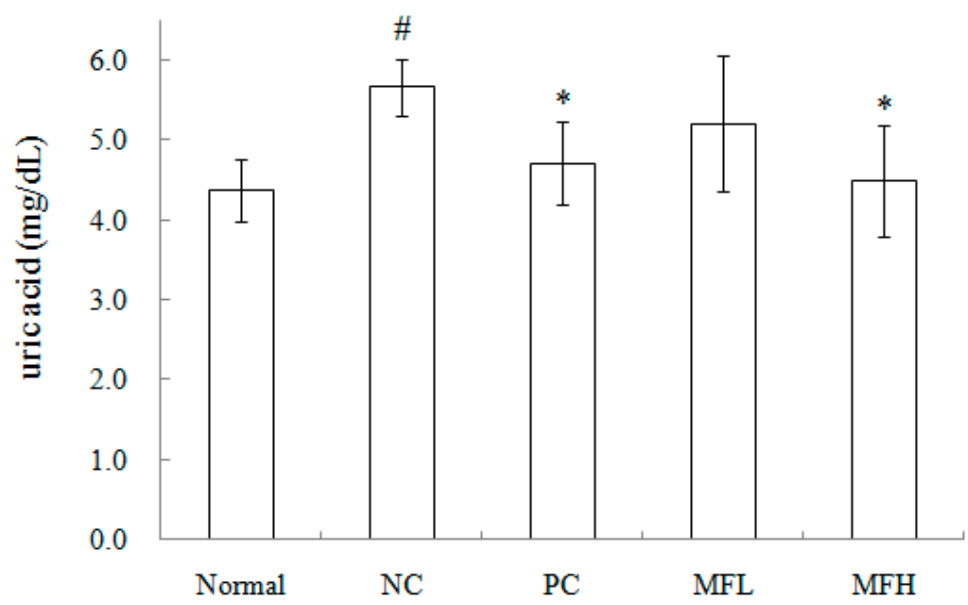

Figure 5. Effect of butanol extract from miracle fruit on the level of serum uric acid in hyperuricemia mice. Each value is expressed as mean \pm S.D. $(n=5)$. Value in a column with the different superscripts are significantly different $(p<0.05)$. Normal: blank, NC: negative control, PC: positive control (allopurinol, $10 \mathrm{mg} / \mathrm{kg} \cdot \mathrm{bw} /$ day), MFL: low dose administration of miracle fruit (butanol extract, $500 \mathrm{mg} / \mathrm{kg} \cdot \mathrm{bw} /$ day), MFH: high dose administration of miracle fruit (butanol extract, $1000 \mathrm{mg} / \mathrm{kg} \cdot \mathrm{bw} /$ day). \# Compared with Normal; * Compared with NC. 


\section{Materials and Methods}

\subsection{Chemicals}

1,1-diphenyl-2-pichryl hydrazyl (DPPH), 2,2'-azino-bis (3-ethylbenzthiasoline-6-sulfonic acid) (ABTS), butylated hydroxyanisole (BHA), peroxidase, potassium hexacyano-ferrate (III), FolinCiocalteu's reagent, $p$-nitroblue tetrazolium chloride (NBT), $2^{\prime}$, $7^{\prime}$-dichlorodihydrofluorescein diacetate (DCHF-DA), and iron(III) chloride were purchased form Sigma (St. Louis, MO, USA). Potassium dihydrogen phosphate $\left(\mathrm{KH}_{2} \mathrm{PO}_{4}\right)$, di-Potassium hydrogen phosphate $\left(\mathrm{K}_{2} \mathrm{HPO}_{4}\right)$ and di-sodium hydrogen phosphate $\left(\mathrm{Na}_{2} \mathrm{HPO}_{4}\right)$ were purchased from Merk (Darmstadt, Germany). Serum uric acid was determined by ELISA kit (Fortress diagnostics). CRE: creatinine (CRE) and blood urea nitrogen (BUN) ELISA kits were purchased from Randox Laboratories Ltd. (Antrim, UK).

\subsection{Sample Preparation}

Miracle fruit was vacuum-dried and ground to a powder. The $25 \mathrm{~g}$ of miracle fruit powder (MFP) was extracted by $250 \mathrm{~mL}$ of water for $40 \mathrm{~min}$, and the extraction solution was filtered, and the filtered liquid was vacuum-concentrated and stored at $-20^{\circ} \mathrm{C}$, it is referred to as miracle fruit-water extract (MFWE). On the other hand, MFP was extracted with butanol, and this butanol extracts were partied by water (water fraction) after filtration. This water fraction was carried out the partition with butanol (butanol fraction), hexane (hexane fraction), and ethyl acetate (EA fraction).

\subsection{Antioxidation}

The DPPH activity was measured by the method of Shimada et al. [21]. Briefly, a sample and a methanolic solution of DPPH were mixed and kept in the dark for $60 \mathrm{~min}$. The absorbance of the reaction mixture at $517 \mathrm{~nm}$ was determined. The antioxidant capacity was determined by the method of Miller and Rice-Evans and Arnao et al. [22,23]. Peroxidase, $\mathrm{H}_{2} \mathrm{O}_{2}$, ABTS, and distilled water were mixed and stored in the dark for $1 \mathrm{~h}$ at $25^{\circ} \mathrm{C}$. A sample was subsequently added and the absorbance at $734 \mathrm{~nm}$ was determined. According to the method of Yen and Chen [24], aliquots of $0.5 \mathrm{~mL}$ extracts after appropriate dilution was mixed thoroughly with $0.5 \mathrm{~mL}$ of phosphate buffer $(0.2 \mathrm{M}, \mathrm{pH} 6.6)$ and $0.5 \mathrm{~mL}$ of potassium ferricyanide solution. All mixtures were incubated in a water bath at $50{ }^{\circ} \mathrm{C}$ for $20 \mathrm{~min}$ and then rapidly cooled in an ice bath. Into each tube, $0.5 \mathrm{~mL}$ of $10 \%(w / v)$ trichloroacetic acid solution was added and thoroughly mixed by vortexing. After centrifugation of the tubes $(1000 \times g$ at $\left.20{ }^{\circ} \mathrm{C}\right), 1.0 \mathrm{~mL}$ of the supernatant was withdrawn and mixed with $1.0 \mathrm{~mL}$ water and $0.2 \mathrm{~mL}$ of $0.1 \%$ $(w / v)$ ferric chloride solution. Then, the mixed solution was incubated the ambient temperature $\left(25-28^{\circ} \mathrm{C}\right.$ ) without light exposure for $10 \mathrm{~min}$ and followed by absorbance determination at $700 \mathrm{~nm}$. The total flavonoid content was determined using the method described by Abu et al. [25]. Briefly, $0.5 \mathrm{~mL}$ of the extract was mixed with $2.25 \mathrm{~mL}$ of distilled water in a test tube followed by addition of $0.15 \mathrm{~mL}$ of $5 \% \mathrm{NaNO}_{2}$ solution. After $6 \mathrm{~min}, 0.3 \mathrm{~mL}(10 \%) \mathrm{AlCl}_{3}$ solution was added and allowed to stand for another $5 \mathrm{~min}$ before $1.0 \mathrm{~mL}$ of $1 \mathrm{M} \mathrm{NaOH}$ was added. The absorbance of the reaction mixture at $510 \mathrm{~nm}$ was determined. Sample was dissolved in deionized water and the concentration of total phenolic compounds was measured by Folin-Ciocalteu's reagent. Sample solution $(100 \mu \mathrm{L})$, Folin-Ciocalteu's reagent $(500 \mu \mathrm{L})$, sodium carbonate $(400 \mu \mathrm{L}, 75 \mathrm{~g} / \mathrm{L})$ and deionised water $(5 \mathrm{~mL})$ were mixed thoroughly and kept at room temperature for $30 \mathrm{~min}$ before the absorbance at $760 \mathrm{~nm}$ was measured. Total phenolic content was determined using gallic acid as the standard [26].

\subsection{Inhibition of Xanthine Oxidase Activity in Vitro}

The $50 \mu \mathrm{L}$ of sample was mixed with $35 \mu \mathrm{L}$ of PBS (70 mM, pH 7.5) and reacted with $30 \mu \mathrm{L}$ of xanthine oxidase $(0.01 \mathrm{U} / \mathrm{mL})$ at $25^{\circ} \mathrm{C}$ for $15 \mathrm{~min}$. Subsequently, the $60 \mu \mathrm{L}$ of xanthine $(150 \mu \mathrm{M})$ was added and reacted for $30 \mathrm{~min}$, this reaction was stopped by HCL $(1 \mathrm{~N})$. The absorbance was measured at $290 \mathrm{~nm}$, and allpourinol was used as the positive control [27]. Inhibitory activity $(\%)=\left(1-\mathrm{A}_{\text {sample }}\right.$ at $290 \mathrm{~nm} /$ A $_{\text {blank }}$ at $\left.290 \mathrm{~nm}\right) \times 100$. 


\subsection{Cell Culture}

The RAW264.7 cell line (BCRC 60001) was obtained from Bioresource Collection and Research Center (BCRC; Food Industry Research and Development Institute, Hsinchu, Taiwan). RAW264.7 cell line was cultured in Dulbecco's Modified Eagle Medium (DMEM, Gibco, Grand Island, NY, USA) supplemented with 10\% fetal bovine serum (FBS, Gibco), $100 \mathrm{IU} / \mathrm{mL}$ penicillin and $100 \mathrm{\mu g} / \mathrm{mL}$ streptomycin (DMEM-FBS) and maintained at $37{ }^{\circ} \mathrm{C}$ in a $5 \% \mathrm{CO}_{2}$ humidified incubator. RAW264.7 cells were treated with various concentrations of samples and MSU $(2.5 \mathrm{mg} / \mathrm{mL})$ for $24 \mathrm{~h}$. The medium was removed to collect cell pellets for measurement of xanthine oxidase according to Orallo et al. [28]. The concentration of uric acid was $1.22 \times 10^{4}(\mathrm{mmol} / \mathrm{mL}) / \mathrm{cm}^{3}$. Thus, the formula was: xanthine oxidase activity $(\mathrm{U} / \mathrm{mg}$ protein $)=\left(\left(\mathrm{dA}_{290} \mathrm{~nm} / \mathrm{min}\right) \times 1000 \times\right.$ time $) /\left(1.22 \times 10^{4} \times\right.$ sample volume $\times$ protein concentration).

\subsection{Animal Model}

Male ICR mice (5 weeks old) (BioLASCO, Taiwan Co., Ltd., Yilan, Taiwan) were housed in individual plastic cages and subjected to a $12 \mathrm{~h}$ light-dark cycle with $60 \%$ relative humidity at $25 \pm 2{ }^{\circ} \mathrm{C}$. The animals were given free access to regular rodent chow diet and water for 1 week to adapt to the new environment. The experiments were carried out in a qualified animal breeding room in the animal center at our institute (Protocol complied with guidelines described in the "Animal Protection Law", amended on 17 January 2001 Hua-Zong-(1)-Yi-Tzi-9000007530, Council of Agriculture, Executive Yuan, Taiwan). The animal study was approved by Institutional Animal Care and Use Committee (IACUC) of National Chiayi University. Animals were randomly divided into 5 groups $(n=5)$, including (1) blank (PBS i.p. injection + PBS oral administration); (2) NC: negative control (i.p. injection with oxonic acid potassium salt; $250 \mathrm{mg} / \mathrm{kg}$. bw for 7 days + PBS oral administration); (3) PC: i.p. injection with oxonic acid potassium salt + positive control (allopurinol, $10 \mathrm{mg} / \mathrm{kg} \cdot \mathrm{bw} /$ day; oral administration); (4) i.p. injection with oxonic acid potassium salt + MFL: low dosage of miracle fruit-butanol extract, $500 \mathrm{mg} / \mathrm{kg} \cdot \mathrm{bw} /$ day; oral administration); (5) i.p. injection with oxonic acid potassium salt injection + MFH: high dosage of miracle fruit-butanol extract, $1000 \mathrm{mg} / \mathrm{kg} \cdot \mathrm{bw} /$ day; oral administration). After administration over 7 days, animals were sacrificed and blood was collected and stored at $-80{ }^{\circ} \mathrm{C}$ until the following experiments.

\subsection{Measurement of Hepatic Xanthine Oxidase Activity}

The hepatic xanthine oxidase activity was determined spectrophotometrically using standard diagnostic kits purchased from Jiancheng Biotech (Nanjing, China). The xanthine oxidase activity is expressed as $\mathrm{nmol} / \mathrm{min} / \mathrm{mg}$ protein.

\subsection{Measurement of Oxidative Stress}

The level of oxidative stress was monitored by the measurement of reactive oxygen species. Collected cells were suspended in $500 \mu \mathrm{L}$ of PBS and mixed with $10 \mu \mathrm{M}$ (final concentration) DCFH-DA to incubate for $20 \mathrm{~min}$ at $37^{\circ} \mathrm{C}$. The cells were washed three times with PBS to remove redundant DCFH-DA. The cell pellet was mixed with $500 \mu \mathrm{L}$ of PBS, and the oxidative stress was assayed by ELISA reader [29].

\subsection{Statistical Analysis}

The analysis of variance was used to evaluate the significance of the differences between factors and levels. Comparison of the means was carried out by employing a Student's $t$-test to identify which groups were significantly different from other groups. The least significant difference was $p<0.05$. 


\section{Conclusions}

Recently, a large of amount of antioxidants including polyphenolic compounds and flavonoids have been found in several berries [30,31]. In addition, other studies also found that antioxidants isolated from strawberries could show the inhibitory effects of inflammation and oxidative stress [32,33]. Currently, MFP, MFWE, and various fractions from miracle fruit have antioxidant effects and can attenuate hyperuricaemia in vitro and in vivo. Taken together, our results suggest that butanol extracts from miracle fruit may be an effective treatment for acute gouty arthritis and could be developed as a health food.

Supplementary Materials: Supplementary materials can be accessed at: http://www.mdpi.com/1420-3049/ 21/2/140/s1.

Acknowledgments: This research work and subsidiary spending were supported by Council of Agriculture, Executive Yuan, Taiwan.

Author Contributions: All the authors contributed sufficiently for their participation in the study, as justified below. She-Ching Wu and Yeu-Ching Shi performed $>50 \%$ of the biochemical analyses, and Kai-Sian Lin prepared the first version of the manuscript, which thus afford all of them as the first authors of this paper. Yi-Fen Jhai, Bao-Hong Lee, Zhibin Cui, and Yifan Han were involved in the experimental design and provided significant scientific suggestions and draft corrections before submission. The corresponding author Wei-Hsuan Hsu and She-Ching $\mathrm{Wu}$ were responsible for financial resources and funds for the project, supervision of the research activities, and submission of the manuscript. The corresponding author Wei-Hsuan Hsu and She-Ching Wu led the research group and drafted corrections.

Conflicts of Interest: The authors declare no conflict of interest.

\section{Abbreviations}

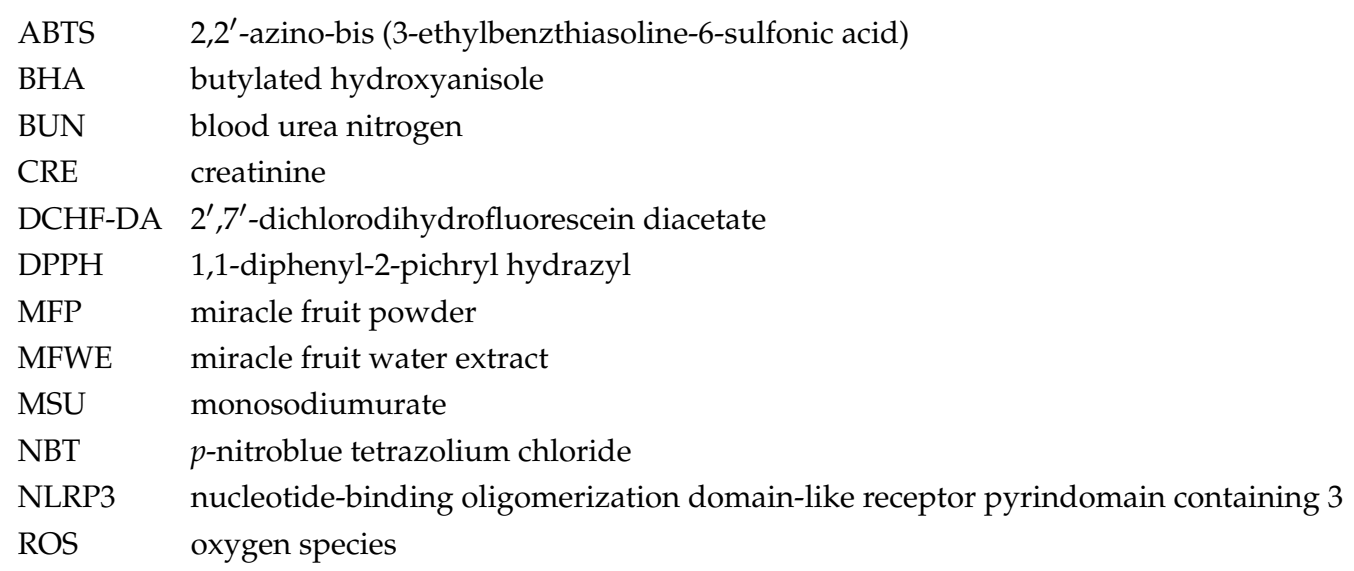

\section{References}

1. Inglett, G.E.; Chen, D. Contents of phenolics and flavonoids and antioxidant activities in skin, pulp, and seeds of miracle fruit. J. Food Sci. 2011, 76, C479-C482. [CrossRef] [PubMed]

2. Du, L.; Shen, Y.; Zhang, X.; Prinyawiwatkul, W.; Xu, Z. Antioxidant-rich phytochemicals in miracle berry (Synsepalum dulcificum) and antioxidant activity of its extracts. Food Chem. 2014, 153, 279-284. [CrossRef] [PubMed]

3. Wong, J.M.; Kern, M. Miracle fruit improves sweetness of a low-calorie dessert without promoting subsequent energy compensation. Appetite 2011, 56, 163-166. [CrossRef] [PubMed]

4. Martin, W.J.; Walton, M.; Harper, J. Resident macrophages initiating and driving inflammation in a monosodium urate monohydrate crystal-induced murineperitoneal model of acute gout. Arthritis Rheum. 2009, 60, 281-289. [CrossRef] [PubMed]

5. Chen, C.J.; Shi, Y.; Hearn, A.; Fitzgerald, K.; Golenbock, D.; Reed, G. MyD88-dependent IL-1 receptor signaling is essential for gouty inflammation stimulated by monosodium urate crystals. J. Clin. Investig. 2006, 116, 2262-2271. [CrossRef] [PubMed] 
6. Zhou, R.; Tardivel, A.; Thorens, B.; Choi, I.; Tschopp, J. Thioredoxin interacting protein links oxidative stress to inflammasome activation. Nat. Immunol. 2010, 11, 136-140. [CrossRef] [PubMed]

7. Jhang, J.J.; Cheng, Y.T.; Ho, C.Y.; Yen, G.C. Monosodium urate crystals trigger Nrf2- and heme oxygenase-1dependent inflammation in THP-1 cells. Cell Mol. Immunol. 2014, 65, 1-11. [CrossRef] [PubMed]

8. George, J.; Struthers, A.D. Role of urate, xanthine oxidase and the effects of allopurinol in vascular oxidative stress. Vasc. Health Risk Manag. 2009, 5, 265-272. [CrossRef] [PubMed]

9. Zhao, F.; Li, G.; Yang, Y.; Shi, L.; Xu, L.; Yin, L. A network pharmacology approach to determine active ingredients and rationality of herb combinations of modified-simiaowan for treatment of gout. J. Ethnopharmacol. 2015, 168, 1-15. [CrossRef] [PubMed]

10. Martinon, F. Signaling by ROS drives inflammasome activation. Eur. J. Immunol. 2010, 40, 616-619. [CrossRef] [PubMed]

11. Huang, J.; Wang, S.; Zhu, M.; Chen, J.; Zhu, X. Effects of genistein, apigenin, quercetin, rutin, and astilbein on serum uric acid levels and xanthine oxidase activities in normal and hyperuricemic mice. Food Chem. Toxicol. 2011, 49, 1943-1947. [CrossRef] [PubMed]

12. Ramallo, I.A.; Zacchino, S.A.; Furlan, R.L. A rapid TLC autographic method for the detection of xanthine oxidase inhibitors and superoxide scavengers. Phytochem. Anal. 2006, 17, 15-19. [CrossRef] [PubMed]

13. Unno, T.; Sugimoto, A.; Kakuda, T. Xanthine oxidase inhibitors from the leaves of Lagerstroemia speciosa (L). Pers. J. Ethnopharmacol. 2004, 93, 391-395. [CrossRef] [PubMed]

14. Bell, P.G.; Gaze, D.C.; Davison, G.W.; George, T.W.; Scotter, M.J.; Howatson, G. Montmorency tart cherry (Prunuscerasus L.) concentrate lowers uric acid, independent of plasma cyaniding-3-O-glucosiderutinoside. J. Funct. Food 2014, 11, 82-90. [CrossRef]

15. Chen, L.; Mola, M.; Deng, X.; Mei, Z.; Huang, X.; Shu, G. Dolichos falcate Klein attenuated the inflammation induced by monosodium urate crystals in vivo and in vitro. J. Ethnopharmacol. 2013, 150, 545-552. [CrossRef] [PubMed]

16. Govardhan Singh, R.S.; Negi, P.S.; Radha, C. Phenolic composition, antioxidant and antimicrobial activities of free and bound phenolic extracts of Moringaoleifera seed flour. J. Funct. Food 2013, 5, 1883-1891. [CrossRef]

17. Wang, Y.; Zhu, J.X.; Kong, L.D.; Yang, C.; Cheng, C.H.; Zhang, X. Administration of procyanidins from grape seeds reduces serum uric acid levels and decreases hepatic xanthine dehydrogenase/oxidase activities in oxonate-treated mice. Basic Clin. Pharmacol. Toxicol. 2004, 94, 232-237. [CrossRef] [PubMed]

18. Zhou, C.X.; Kong, L.D.; Ye, W.C.; Cheng, C.H.K.; Tan, R.X. Inhibition of xanthine and monoamine oxidases by stilbenoids from Veratrum taliense. Planta Med. 2001, 67, 158-161. [CrossRef] [PubMed]

19. Yen, J.H.; Lin, L.C.; Chen, M.C.; Sarang, Z.; Leong, P.Y.; Chang, I.C. The metastatic tumor antigen 1-transglutaminase-2 pathway in involved in self-limitation of monosodium urate crystal-induced inflammation by upregulating TGF-beta1. Arthritics Res. Ther. 2015, 17. [CrossRef]

20. Ives, A.; Nomura, J.; Martinon, F.; Roger, T.; LeRoy, D.; Miner, J.N. Xanthine oxidoreductase regulates macrophage IL1beta secretion upon NLRP3 inflammasome activation. Nat. Comm. 2015, 6. [CrossRef] [PubMed]

21. Shimada, K.; Fujikawa, K.; Yahara, K.; Nakamura, T. Antioxidative properties of xanthan on the autoxidation of soybean oil in cyclodextrin emulsion. J. Agric. Food Chem. 1992, 40, 945-948. [CrossRef]

22. Miller, N.J.; Rice-Evans, C.A. The relative contributions of ascorbic acid and phenolic antioxidants to the total antioxidant activity of orange and apple fruit juices and black currant drink. Food Chem. 1997, 60, 331-337. [CrossRef]

23. Arnao, M.B.; Cano, A.; Acosta, M. The hydrophilic and lipophilic contribution to total antioxidant activity. Food Chem. 2001, 73, 239-244. [CrossRef]

24. Yen, G.C.; Chen, H.Y. Antioxidant activity of various tea extracts in relation to their antimutagenicity. J. Agric. Food Chem. 1995, 50, 6929-6934. [CrossRef]

25. Abu Bakar, M.F.; Mohamed, M.; Rahmat, A.; Fry, J. Phytochemicals and antioxidant activity of different parts of bambangan (Mangiferapajang) and tarap (Artocarpusodoratissimus). Food Chem. 2009, 113, 479-483. [CrossRef]

26. Hsu, W.H.; Lee, B.H.; Pan, T.M. Red mold dioscorea-induced G2/M arrest and apoptosis in human oral cancer cells. J. Sci. Food Agric. 2010, 90, 2709-2715. [CrossRef] [PubMed]

27. Nguyen, M.T.T.; Awale, S.; Tezuka, Y.; Tran, Q.L.; Watanabe, H.; Kadota, S. Xanthine oxidase inhibitory activity of Vietnamese medicinal plants. Biol. Pharm. Bull. 2004, 27, 1414-1421. [CrossRef] [PubMed] 
28. Orallo, F.; Álvarez, E.; Camiña, M.; Leiro, J.M.; Gómez, E.; Fernández, P. The possible implication of trans-resveratrol in the cardioprotective effects of long-term moderate wine consumption. Mol. Pharmacol. 2002, 61, 294-302. [CrossRef] [PubMed]

29. Lee, B.H.; Hsu, W.H.; Huang, T.; Chang, Y.Y.; Hsu, Y.W.; Pan, T.M. Effects of monascin on anti-inflammation mediated by Nrf2 activation in advanced glycation end product-treated THP-1 monocytes and methylglyoxal-treated Wistar rats. J. Agric. Food Chem. 2013, 61, 1288-1298. [CrossRef] [PubMed]

30. Nestby, R.; Krogstad, T.; Joner, E.; Vohnik, M. The effect of NP fertilization on European blueberry (Vaccinium myrtillus L.) development on cultivated land in mid-Norway. J. Berry Res. 2014, 4, 147-157.

31. Pissard, A.; Lateur, M.; Baeten, V.; Magein, H.; Dupont, P.; Tabart, J.; Pincemail, J.; Kevers, C. Determination of total phenolic compound content and antioxidant activity in cherry species and cultivars. J. Berry Res. 2015. [CrossRef]

32. Forbes-Hernandez, T.Y.; Gasparrini, M.; Afrin, S.; Bompadre, S.; Mezzetti, B.; Quiles, J.L.; Giampien, F.; Battino, M. The healthy effects of strawberry polyphenols: Which strategy behind antioxidant capacity? Crit. Rev. Food Sci. Nutr. 2015. [CrossRef] [PubMed]

33. Giampieri, F.; Alvarez-Suarez, J.M.; Mazzoni, L.; Forbes-Hernandez, T.Y.; Gasparrini, M.; GonzalezParamas, A.M.; Santos-Buelga, C.; Quiles, J.L.; Bompadre, S.; Mezzetti, B.; et al. An anthocyaninrich strawberry extract protects against oxidative stress damage and improves mitochondrial functionality in human dermal fibroblasts exposed to an oxidizing agent. Food Funct. 2014, 5, 1939-1948. [CrossRef] [PubMed]

Sample Availability: Not available.

(C) 2016 by the authors; licensee MDPI, Basel, Switzerland. This article is an open access article distributed under the terms and conditions of the Creative Commons by Attribution (CC-BY) license (http://creativecommons.org/licenses/by/4.0/). 